\title{
Expanding your practice goes beyond face-to-face
}

\author{
Shanda H. Blackmon, MD, MPH
}

\author{
From the Division of General Thoracic Surgery, Mayo Clinic, Rochester, Minn. \\ Disclosures: Author has nothing to disclose with regard to commercial support. \\ Received for publication Feb 18, 2016; accepted for publication Feb 19, 2016. \\ Reprint requests: Shanda H. Blackmon, MD, MPH, Division of General Thoracic Surgery, Mayo Clinic, 200 First \\ St SW, Rochester, MN 55905 (E-mail: Blackmon.Shanda@mayo.edu). \\ J Thorac Cardiovasc Surg 2016;151:1465 \\ $0022-5223 / \$ 36.00$ \\ Copyright (c) 2016 by The American Association for Thoracic Surgery \\ http://dx.doi.org/10.1016/j.jtcvs.2016.02.045
}

This issue of the Journal includes an article by Klapper titled "The necessity of self-promotion: A key component to early practice building." 1 The review of practice development begins with an anecdotal story and literature references and covers everything from referral practice patterns, to understanding the dynamics of your medical community, to knowing the demographics of where you practice. The author makes several valid points that should be included in the reading list of every graduate headed into clinical practice: meet face-to-face, work with providers who are also in the early stages of their practice, articulate what you do that is either more beneficial for the patient or superior to your competition, and widely distribute your cell phone and contact information (and respond "yes" to calls, even in the middle of the night). Stepping up to medical disasters is one of the best ways to build a coalition of grateful patients and doctors.

Although this tribute to face-to-face interaction is helpful, it lacks what I would call a more modern approach. These are all things many of us should know and practice throughout our careers. In addition to the aforementioned practices, I would suggest that more meaningful personal interactions between providers would include making a phone call at the end of a case (or at discharge), telling the referring physician how a surgery went, sending a summary note, and coordinating a survivorship plan.

Those modern additions to expanding clinical practice may include convening a support group, creating a Facebook support page, enhancing patient education by making videos to educate patients and providers as a reference, recording your entire case and providing your patient or provider with a copy, using multimedia to enhance your provider's understanding of what you offer, and participating in Twitter chats, webinars, or podcasts. Each of these has the potential to reach innumerable persons who may refer to you.

In contrast to focusing on the provider to expand your practice, I would also argue that the person you should be focusing on is the patient. More now than ever, we are

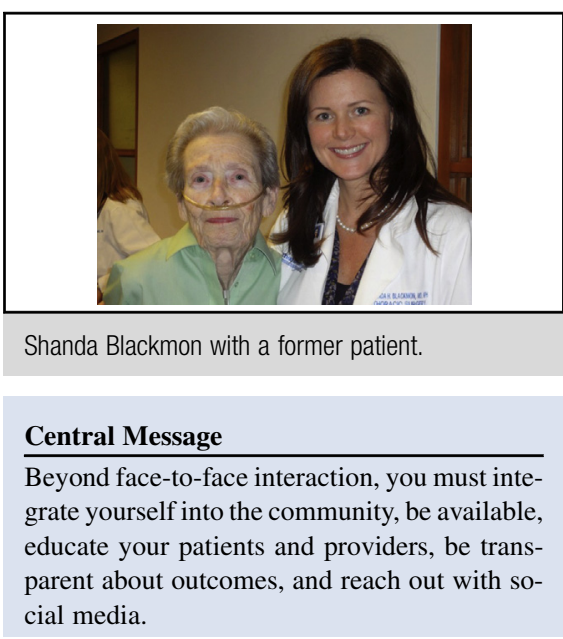

See Editorial page 1462.

finding that patients are willing to travel to destination medical centers for second opinions, less invasive surgery, or more advanced care. Patients are beginning to educate themselves, find their own doctors, and seek what they think is the best care they deserve. Patients talk to one another. Many of my best referrals came out of a support group that I ran for 8 years. Skillfully handling another surgeon's complication with a good outcome creates an incredibly grateful patient. Those patients are likely to recommend you to friends or family with similar problems.

One other arena of outreach is the surrounding community. Becoming an integral part of the community within which you live and practice often results in the best referral pattern. Volunteering in your church, synagogue, local charity organization, and giving back to the community will always come full circle.

Essentially, to be the best surgeon you can be, you must be a good citizen, integrate yourself into the community, be available, educate your patients and providers, be transparent about your outcomes, and reach out with both social media and face-to-face interaction. Gone are the days when a surgeon could just play golf with his buddy and get referrals based on friendship with no regard to patient preference. Ignoring what the patient wants could mean no patients.

\section{Reference}

1. Klapper JA. The necessity of self-promotion: A key component to early practice building. J Thorac Cardiovasc Surg. 2016;151:1462-4. 